\title{
Yoksulluk ve sosyal yardım şekilleri
}

\author{
Dog. Dr. Vedat DícLELI
}

\begin{abstract}
I - Yoksulluk ve sebepleri; - II. Yoksullara yardim șekilleri: A. Fertler tarafından yapılan yardımlar - al lâkì ve dinî endişeler - Sosyal yardım cephesinden vakiflar - B. Hayır Kurumları tarafindan yapilan yardimlar - Kizılay Kurumu - Cocuk Esirgeme Kurumu - Yardım Sevenler Kurumu - Hayır Kurumları tarafıtzdan yapılan yardımlarm mahdutiuğu $-\mathrm{C}$. Devlet eliyle sosyal yardum - Sağlik ve Sosyal Yardım Bakanlı̆̆ - Belediyelerin sosyal yardım hizmetleri - Devlet ve Belediyeler tarafindan yapilan sosyal yarđimların yetersizliği - Sosyal sigortaların mahiyet ve önemi - Netice.
\end{abstract}

\section{I - YOKSULLUK VE SEBEPLERI}

Her toplulukta çeştli ekonomik faaliyetler sonunda bir çok yeni kiymet ve servetler meydana gelir. Bir yıl içinde yaratılan bu ekonomik değerlere "millî gelir» adı verilir. Bir merileketin millî ggehiri ne kadar yüksek olursa o memleket o derece zengin sayllı. Fakat en zengin topluiuklarda bile bir çok fakir ve yoksul yurttaşlara rastlanmaktadır. Zira millî gelirden herkes lâyikìe pay alamamaktadir. Bazı insarılar cok kazanı, kolayca harcadikları halde, bir k1sım insanlar bütün yorgunluk ve çabalamalarma ruğmen az kazanirlar ve millî gelirin ellerine geçen mutavazi cüz'i ile geçimlerini săglamakta zorluk çekerler. Bazı hallerde ise bu mahdut imkânlar bile ortadan kalkar ve yoksulluk iyiden iyiye baș gösterir. Meselâ, gündeliği ile yaşamakta olan bir işçinin bir iş kazașna maruz kalmast veya günü gününe hayatmı kazanan bir lkimsenin ihtiyarlık veya hastalık yüzünden çalışamıyacak bir duruma düșmesi bu tehlikeli ihtimallerdendir. Çalışma yaşına varmamış çocuklarla, kimsesiz ve dul kadmları da hesaba katacak olursak, bir topluluk içerisinde yoksulluk sebep ve ihtimallerinin ne kadar çeşitli ve çok olduğu kolayca anlaşilur. 
Kazanç imkânlarının az ve geçim şartlarının ağır olduğu büyük şehirlerde ise yoksulluk daha bariz bir şekilde göze batar. Gerçekten yol kenarlarinda sokak başlarında ve cami avlularında her gün yüzlerce sákat ve yaşlı dilencilerle serseri çocuklar önünüze çlkmakta ve insanlik duygumuza avuç açmaktadırlar; bunlara dilenmeği nefsine yediremeyip bir köşede kıvrılıp kalan diğer bir çok yoksulları da ilâve etmek gerekir.

Hayatları ancak başkalarının yapacağı yardımlara bağı kalan bu insanların sefalet içinde kalmalarına kim sebep olmuştur? Bizzat kendileri mi, yoksa fertleri arasında bir kader beraberliği olan topluluk mu? Bu konu üzerinde kafa yoranlardan bir kısmı, yoksulluğun asıl sebebini şahısta aradıkları halde, diğer bir kısmı bu durumdan daha çok topluluğu sorumlu tutmak isterler. Her iki görüşün de haklı olduğu taraflar yok değildir. Ferdin tembellıği, ihmali, kayıtsizlığı ve israfi yoksulluğu davet edebileceği gibi, topluluğun kültür durumu, sağlık derecesi, düşünüş tarzı ve kazanç imkânlarınm dar veya genis olması da yoksulluk üzerine etki yapabilir. Bazan ne ferdin ve ne de topluluğun hiç bir kusuru olmadan dahi bir kısım yurttaşlar yoksulluk içinde kalabilirler. Umulmadık bir hâdise, büyük bir âfet veya kökü çok derin ve uzakta olan ekonomik krizler birer sefalet sebebi olabilirler.

Sebep ve âmilleri ne olursa olsun, bütün topluluklarda bir k1sım insanlar yoksulluk içinde kıvrandıklarına göre bu meseleyi görmemezlikten gelmeğe ve bu sosyal derdi inkâr etmeğe imkân yoktur. Zenginliğin derecesi ne olursa olsun her cemiyette sefalet içinde kalan bir çok yurttaşlar vardır. Burada hatira şöyle bir soru geliyor: Yoksulluk içinde kalan yurttaşlarm topluluktan yardım istemeleri bir hak midır ve bu duruma düşen insanlara cemiyetin el uzatması bir borç mudur? Bazı kimseler topluluğun yoksullara yardm etmek mükellefiyetinde olduğunu kuvvetle müdafaa ederler; zira bunlara göre yoksulluk muhakkak ferdin yanlış bir hareketinden değil, biraz da topluluğun hatasından ileri gelmektedir. Cemiyet ilerlememiş, kültür imkânları gelişmemiş, yurttaşlar gereği kadar aydmlatılmamış ve herkese bir kazanç yolu sağlanamamış ise kusur daha çok cemiyete aittir. İşte, topluluk yoksullara yardm etmek suretile bir hatanın telâfisine çalışmış olur. Diğer bir kısım kinseler ise cemiyetin yoksullara el uzatmasm şiddetle tenkit ederler; onlara göre çalışkan yurttaşların kazançlarma ortak olmak suretile toplanan devlet geiri ile yoksullara yardım etmek devleti israfa ve bir çok 
insanları tembelliğe götürür. $\mathrm{Bu}$ aşırı düşüncede olanlar. devletin her yardımını tembelliğge verilmiş bir prim şeklinde telâkki ederler.

Zannımizca, bu yoldaki tartışmalarm pratik bir değeri yoktur. Sebep ve saikine bakmadan meydana gelen yoksulluğun giderilmesi veya hiç olmazsa tahfif ettirilmesi lâzımdır. Zira, yoksulluk yalnız bu duruma düşen yurttaşların değil, bütün topluluggun huzurunu kaçrır. Sebebi ne olursa olsun devrilen bir lokomotifi yol üstünde birakmak icabetmez (1).

\section{YOKSULLARA YARDIM ŞEKILLERİ}

Sosyal yardim fikri yeni değildir. Tarihin her çağında ve her toplulukta insanlar yoksul ve düşkünlere yardım etmeği manevî bir borç saymışlar ve hiç bir karşlık beklemeden müskül durumda bulunan hemeinslerinin acıların hafifletmeğe koşmussiardır. Yalnız yoksullara yapılan yardımlar zamanın zihniyet, imkân ve görüșüne göre şekil değiştirmiş, iptidaî bir şekilden başlıyaiak gittikçe organik ve resmî bir mahiyet almıştır.

A. Fertler tarafından yapllan yardımlar:

Sosyal yardım alanında hiç bir resmî teşkilâtm bulunmadiğı zamanlarda bile fakirlerin yardımına koșulmuştur. Acımak duygusu insanları harekete getirir ve hamiyetli yapar. Yoksullara yardım işleri bu insanî duygu sayesinde büyük gelişmeler göstermiş ve boğaz ve miğde savaşını bu günkü kadar şiddetli olmadığı ve ahlâkî endişelere geniş ölçüde yer verildiği devirlerde, insanlar kendiliklerinden sefaletin ortadan kalkmasına çalışmı̧̧lardır.

Fertleri düşkünlere el uzatmağa sevkeden diğer manevî bir kuvvet de dinsel vecibelerdir. Gerçekten her dinin tasvir ettiği iyilik ve kötülü̈klerin muhasebesinin yapılacağ́ günde takdir edilmek ümidi insanların yoksullara karş̧ yakm bir ilgi göstermesine yol açmıştrr. Nitekim islâm dininde yoksul insanlara yardım işleri bir borç saylmıs ve hali vakti yerinde olan insainlar sosyal yardım alanında maddî fedakârhlkta bulunmağ̀a davet edilmișlerdir.

İslâm dininin sosyal amacı olan müesseselerì arasinda zekât müessesesine özel bir yer vermek yerinde olur. Âmiller tarafından toplanan zekât, müslümanlığın kuruluş̧ ylllarmda, beytülmâl için büyük bir gelir kaynağı teşkil etmiştir. Bu suretle elde edilen gelirin sarf mahalleri ise şu şekilde tesbit edilmişti:

(1) L. Ferrand - Problèmes d'économie politiques et sociales S. 701. 
a) Fakirlere ve miskinlere yapılan yardımlar;

b) Zekât memurları ücretleri;

c) Yeni müslüman olanlara yapılan yardımlar;

c) Azat edilen köle ve cariyelere yapllan yardımlar;

d) Borcu olup da borçlarını ödeyemiyenlere yapılan yardımlar;

e) Cihat eden gazilere yapilan yardımlar;

f) Ailesinden ve malinden uząk düşen yolculara yapılan yardumlar.

Görülüyor ki, zengin müslümanlarnn para, mal, hayvan, mahsul ve kıymetli madenlerinden muayyen bir miktarınm topluluğa terketmeleri suretile elde edilen maddî kaynaklarır çok önemli bir kısmı topluluk içinde yardıma muhtaç olanlara tahsis edilmektedir. Müslüman devletlerde hazine başka gelir kaynakları sağladıktan sonra, zekât fertler tarafından doğrudan doğruya yoksul insanlara yapılan münferit yardımlar mahiyetini almıştır.

Ahlâkî ve đinî etlkiler altında fertler tarafından meydana getirilen en ileri ve teşkilâtlı yardım şekli hiç şüphesiz tesislerdir. Her memlekette yoksullara yardım etmek ve topluluğa faydalı olmak maksadı ile bir çok tesisler kurulmuş aşhane, imaitethane, ve hastahaneler meydana getirilmiştir. Bu alanda memleketirnizde bütün dünyaya nümune teșkil edebilecek mükemmeliyette vakıflar tesis edilmiştir. İslâm dininin sosyal yönünü belirtmek için vakıflardan daha güzel bir misal olamaz. Vakıf müessesesini «bir malin menafii vücuhu hayra sarfolunmak üzere o malı müebbeden hapsedip anî mâmelekten çıkarmak ve Allahı Zülcelâlin mülkü hükmünde kılmaks şeklinde tarif eden İzmirli İsmail Hakkı Anglikan klisesine verdiği cevapta vakfın lüzum ve değerini şu surette belirtmektedir: "Vakfin meşruiyetinde bir çok hüküm ve mesalih vardır. Ezcümle insanlar arasında kisipten âciz kimseler bulunur; bu gibi eşhas cemiyeti insaniyenin merhametine, şefkat ve atıfetine lâyık bulunmaktadir; bu halde bir mal ayırıp da anın nemâsından bunlara tasadduk edilirse anlar zayk1 maişetten kurtulur» (2).

Fertler tarafından yapılan sosyal yardım alanında çok önemli bir yer işgal eden vakıflar Türk ruhundaki ferağat, fazilet, millî dayanışma ve sosyal yardım hasletlerini canlandıran bir müessesedir. 1937 yllında Vakıflar genel müdürlüğü tarafından hazırlanıp Türk Tarih Kurumuna sunulan raporda vakıfların ifa ettiği hizmetler şu şekilde hulâsa edilmektedir: "Vakıfların çoğu atalarımızın derin

(2) İzmirli İsmail Hakkı - Anglikan klisesine cevap S. 83 ve 84 . 
görüs ve güzel buluşlarına birer belgedir. Bunların içinde ibadet ve sevap kastı ile veya vâkıfın çoluk ve çocuğunun âtisini emniyet altma almak emeli ile vücude getirilenler bulunduğu gibi, bir çoğu da yurdun imarı, düşman tecavüzünden muhafazası ve içtimaí bünyenin korunmasi gibi pek yüksek ve șümuliü hedeflere taallûk eder. Bunlardan hatira gelenleri saymak az çok bir fikir vermeğe yarar: $\mathrm{Su}$ yolları ve kemerleri, çeşme ve sebiller, yol, kaldırım, köprü, aş evi misafir evi, dul evi, muvakkithane, rasathane, mektep, medrese, kütiiphane, hastahane, vakufları hemen her yerde bulunan, görülen vakıflardandır. Bundan başka öksüz kızlara cihaz verilmesi, borçlu olarak mahpus bulunaniarın borçlarmm ödenmesi, müflis olarak hapsedilenlerin tahliyesi, köy ahalisinin ihtiyarlarına elbise verilmesi, manalleler veya köy tekâlifine imdat edilmesi, kale ve istihkâmlara veya donanmaya muavenette bulunulması, askerin teçizi, zahire loncaları tesisi, deniz feneri inşası, yetimlere, dul kadmlara ve muhtaçlara yardım edilmesi, çocukların baharda açı havada gezdirilmesi, mektep çocuklarına gıda, elbise, tedris levazımı, mahrukat ve mesire masrafi tesisi, fakir çocuklara, dullara ve ihtiyar fukaraya elbise ve zahire verilmesi, fakirlerin ve kimsesizlerin cenazelerinin kaldırılması, çamaşıhane tesiși, bayramlarda çocukların ve fakirlerin sevindirilmeși, açık hava mektepleri, spor meydanları ve teşkilâtı vücude getirilmesi, kuşlara yem ve hayvanlara gıda verilmesi... Vesaire gibi hizmetlerin ifası için ihdas edilmiş olan son ilrnî telâkkkileri ve muvaffakıyetleri okşayan vakıflar da vardır” (3).

Görülüyorki, Türk camiasinda hali vakti yerinde olan fertler, vakıf müessesesi sayesinde, münferit fakat sürekli bir șekilde topluluğun bir çok dertlerine ilgi göstermişler ve bilhassa yoksul ve düşkünlere yardım hususunda öğülmeğe değer bir endişe izhar etmişlerdir. $\mathrm{Ne}$ yazık ki, bu kadar yüksek amaçlai peșinde koşan vakıf müessesesi, Imparatorluk idaresinin son devirlerinde, Babüsseâde ve Darüsseâde ağaları gibi cahil kimselerin elinde özel maksatlar uğrunda soysuzlaştırılmıştır. Nihayet 1823 yılında kurulan «Evkaf Nezaretin de vakıflara arzu edilen istikameti verહmemiştir. Mahlûl sayılan bir çok vakıf mallar tahsis alanından uzaklaștırılmış ve saray halkına dağıtılmıștır.

(Eğer vakıflara gayenin ehemmiyet ve azameti ile mütenasip bir idare şekli verilmiş olsaydı, şimdi memleketimizin her tarafında büyük hastahaneler, muavenet yuvaları görmek miümkün olacak ve

(3) Cümhuriyetten önce ve sonra vakıflar. Rapor S. 5 
vakıflar idaresi hakikî bir muaveneti içtimaiye kaynağı haline gelmis olacaktın (4).

Cümhuriyet idaresi ile vakıflara amacina uygun bir mahiyet ve idare şekli verilmeğe çalışılmıştır. 1926 yılında çıkarılan Medenî Kanunun yürürlüğe girmesinden sonra hayir işleri için yapllan vakiflar "tesis" hükümlerine tâbi tutulmakstadır. Medenî Kanundan önce yaplan vakıflar ise 1935 yllında çıkarılan "Vakıflar Kanunu" hükümlerine göre idare edilmektedir.

Bugün vakıflar mülhak ve mazbut vakıflar olmak üzere bir tasnife tâbi tutulmuştur. "Mülhak Vakıflar» Mütevelliler tarafindan idare edilmrektectir: Mütevelliler vâknflarm vakfiyelerinde yazrlı olan şartları yerine getirmek ve vakıf akarlan idare etmekle mükelleftirler. Ayrı birer tüzel kişi sayılan mülhak vakıflar Vakıflar genel müdürlüğünün denetlemesine tâbidirler. "Mazbut Vakıflar" ise doğrudan doğruya "Vakıflar Genel Müdürlüğ̈̈» tarafından idare edilmektedir.

Hamiyetli ve fazilet sahibi yurttaşlar tarafından tesis edilmiş olan vakıfların bugün amacına uygun bir şekilde idaresine çalışlmaktadır. Bu maksatla "Vakıflar Idaresi» bir çok okul binası yaptırmış, hastahaneler kurmuş, Ưniversiteye, Darüşşafakaya, Kuzılay ve Çocuk Esirgeme Kurumlarma, Belediyelere, öğrenici yurtlarma spor kulüplerine yardımlarda bulunmuştur. Ayrıca aş evleri açmış, çocuklara, muhtaçlara ve ağmalara el uzatmıştır. İkỉnci Dünya savaşında geçimlerini sağlamakta büyük sıkıntı çeken bir. kısım fakir halka kömür dağıtmış, vereme istidatlı olan yurttaşlara kuvvetli gidalar sağlamak üzere teşebbüslere girişmiştir.

Hiç şüphesiz bugünkü hali ile dahi Vakıflar İdaresi hayırlı işler başarmaktadir. Fakat bütün Vakıflar bir araya getirilir, yeniden düzen altına alınır ve rasyonel bir idareye tâbi tutulursa sosyal yardım davasına değerli bir kaynak elde edilmiş olacaktır. Bugün mütevelliler elinde tesis amacından tamamile uzaklaştırımış bir çok vakuflar vardır. Dağınık ve verimsiz bir şekilde duran bu vakıfları esasli bir müşahede ve incelemeğe tâbi tuttuktan sonra büyük imkânlar elde edilmesi çok muhtemeldir. Bütün yurttaşlara asgarî bir geçim ve memlekette sosyal huzuru sağlamak için harcanacak gayretler hazinenin kaldıramıyacağı derecede ağır masraflara yol açabilir. Iş̧te bu masrafların hiç olmazsa bir kısmı yurdumuzun her tarafına serpilmiş olan vakfiyelerin ekonomik bir zihniyetle işletilmesi

(4) Ali Himmet Berki Vakuflar. 
ve değerlendirilmesi suretile karşlamak imkânsız değildir. Íleride iş̧̧i sigortalaŕ genişleyip, daha fazla insanı daha çeşitli rizikolara karşı koruyan sosyal sigortalar kurulurken vakuflardan istifade edilmesi ciheti her halde düșünülmelidir.

Din ve ahlâk endişeleri ile yoksullara yapılmakta olan ferdî yardımların yapılış şekli ne suretle olursa olsun, genel olarak fertler tarafindan yaplan yardimların bazı mahzurlu tarafları vardır. $\mathrm{Bu}$ şekilde yapılan el uzatmaların en zayıf tarafı bu yardımların düzenli bir şekilde olmayışıdır. Gerçekten acımak duygumuza sığınan bir kısım yoksullar günlük geçimlerini sağliyabildikieri halde, köşede bucakta kalıp, ortaya çlkmıyan bazı fakir aileler bir lokma ekmek bile elde edememektedirler. Hangi yoksula ne miktarda yardım yaplacağını bir fert kestiremez; yardım ettiği bir yoksula kendisinden önce ihtimal on yurttaş daha alâka göstermiş olduğu halde yardım etmeden geçtiği bir fakire belki de o gün hiç kimse bir şey vermemiştir. Bundan başka, bu münferit yardimlardan bütün yoksullar faydalanmış olsalar bile, her birinin eşit bir şekilde yardım görmüş oldukları ileri sürülemez. Yırtık ve cerbezeli kimseler iyi yürekli insanlardan lüzumundan fazla yardım elde edebildikleri halde, bir kısım fakirler ancak mahcup ve ürkek nazarlarla merhametimize sığınmaktarırlar. Dilenciliği bir meslek olarak benimsemiş bir çok kimselerin bunlarm yardımma koşan yurttaşlardan daha zengin oldukları çok görülmüştür. Fert bütün iyi niyet ve dikkatine rağmen topluluk içerisinde kimin daha çok yardıma muhtaç olduğunu kolay kolay kestiremez.

B. Hayir Kurumlarm tarafindan yapilan yardzmlar:

Bütün medenî memleketlerde sosyal yardım işleri bu maksatla teşekkül etmiş olan hayır kurumları vasıtasile yapılmaktadır. Düşkün ve fakirlere yardım etmek istiyen yurttaşlar topluluğun himayesine muhtaç olanları teker teker arayıp bulmak yorgunluk ve zorluğundan kurtulmakta ve yapmak istediği yardımm maksadına ve sarf mahalline uygun bulduğu, hayır kurumlarından birine bağışlarda bulunmaktadırlar. Fertlerin hayır kurumları vasıtasile yoksullara yardım etmeleri, doğrudan doğruya yapılan münferit yardımlardan çok daha faydalı ve verimlidir. Gerçekten fert bütün iyi niyet ve dikkatine rağmen topluluk içerisinde hakikî yoksulları bulup çlkarmakta büyük zorluklar karşısında kaldığı ve çok defa isabetsizlik gösterdiği halde, genis teşkilât ve elemanlar olan hayır kurumları sürekli bir araştırma ve müşahede ile gerçek yoksulları arayıp bulmaktadır. Bundan başka hayır kurumları tuttukları kayıt- 
lar sayesinde aynı kimseye lüzumundan fazla yardım yapılıp, diğer yardıma muihtaç olanların yüzüstü bırakılmalari tehlikesinin önüne de geçebilmektedir.

Memleketimizde sosyal yardım davasında gönüllü çalışan çeşitli hayır kurumlarımız vardır:

1) KIZILAY KURUMU:

Cenevre mukavelenamesine uyularak, memleketimizde ilk defa 1877 yilında "Osmanlı Hilâliahmer Cemiyeti" adı ile bir cemiyet kurulmuştur. Geçen yüzyıl sonlarında büyük bir faaliyet gösteremiyen bu Kurum 1911 yllında ihya olunmuş ve Birinci Dünya savaşında cephe ve cephe gerisinde büyük işler başarmıştır. 1923 yılında "Türkiye Hilâliahmer Cemiyeti» adını alan Kuruma 1935 yılındanberi (Türkiye Kiznlay Cemiyeti» denmektedir.

Kızılay bütün muamelelerinde 1865 ve 1906 Cenevre ve 1907 Lâhey konferanslarında verilmiş olan kararlara uymak suretile hareket eder.

Başka memleketlerde “Kızılhaç» in mâlik olduğu muafiyetlere sahip bulunan Kızılayın savaş ve barı̧ zamanlarında olmak üzere iki çeşit ödevi vardır.

Savaş sırasınḍa, Kızılay Kurumu şu yardımlarda bulunur:

a) Türk ve düşman askerlerinden yaralı ve hastalar ile zayıf ve malûllerin tedavilerine ve acılarının hafifletilmesine çalışır.

b) Hastabakıcı ve hastabakıcı yardımclarının tedarikine gayret eder.

c) Hasta ve yaralıların nakli için gereklì nakil araçlarını şă̆lamağa yardım eder.

ç) Askerî sağlık kurumlarına sağlık ve gıda levazımı vermeğe çalışır.

d) Askerî makamların göstereceği yerlerde hastahaneleri idare eder.

e) Ordularda bulaşıcı hastalıklara karşı açılacak mücadelelere iștirak eder.

f) Savaşta sakatlananlara sun'î alettler imal etmeğe çalışır.

g) Türk ve düşmanan asker esirlerinin aileleri ile mektuplaş̧malarını, para ve eşya naklini sağlamağa tavassut eder. sitlidir:

Barış yıllarmda ise Kızılay Kưrumunun çalışma kolları daha çe- 
a) Salgın hastalıklara, verem, sitma ve çotuk veffiyatı gibi sosyal âfetlere karşı girişilen mücadelelere yardım eder.

b) Hastabakıcilar yetiştirir.

c) Büyük yangın, deprem, sel, kıtllk ve savaş yüzünđen göç gibi âfet ve musibetlerden biri vukuunda mümkün olan yardımda bulunur.

ç) Kurumun savaş zamanındaki ödevlerini yapmak için gerekli yaraç ve araçları muayyen yerlerde depo eder.

Bundan başka Kızlay son yıllarda tahsilde bulunan gençlerle yakından ilgilenmiş ve yardıma muhtaç olanlara el uzatmıştır.

Savaş ve barış yıllarında yapmakla ödevli olduğu işlerini kısaca saydığımız Kızılay büyük işler başaran ve bir çok sosyal dertleri hafifleten bir Kurum olduğunu çoktan isbat etmiş bulunmaktadır.

Savaşın önüne geçemiyen milletler hiç olmazśa savaş yüzünden meydana gelen ıstırapları biraz olsun dindirmek amacı ile bu teşkilâtın her memlekette kurulmasını candan arzu etmişler ve bu $\mathrm{Ku}$ rumu yakın bir ilgi ile göstermişlerdir.

Kızılayın, üyeleri okul çocuklarmdan mürekkep ayrı bir gençlik kurumu da vardır. İlk defa Birinci Dünya savaşında Kanada'da kurulan ve tecrübe edilen bu teşkilât büyük hizmetler başardığından bir çok memleketlerde meydana getirildi. Bizde de 1933 yllında “Klzllay Gençlik Kurumu" adı ile bir kurum kuruldu. İlk ve orta okullarla ,meslek okulları ve liselerde dernek kolları ı́şekkül etti. Yaşama şartlarmın gittikçe ağirlaştığ olduğu bir devirde, körpe kafalarda hasis düşüncelere yer vermemek cocuklarda yardım ve tesanüt duygularmı kuvvetlendirmek ve bu suretle ileride Kızılay kurumuna ferağat sahibi genç üyeler kazandıkları bu kamplar çok faydalı olmaktadır. Şahsiyetin gelişmeğeri vardır.

Kızllay gençlik kurumu en verimli faaliyetini yaz kamplarmda göstermektedir. Her yıl birkaç bin fakir çocuğun sağlık ve neşe kazandıkları bu kamplar çok faydah olmaktadır. Şahsiyetin gelişmesinde, yardımlaşma fikrinin kökleşmesinde büyük faydası olan açık hava kamplarına lâyık oldukları itinayı göstermek lâzımdır. TopIuluğun geniş bir aileden ibaret olduğunu ve her gün bir iyilik yapmanın bir vicdan borcu olduğunu telkin eden izcilik müessesesinden de sosyal yardım fikrinin kökleşmesi yolunda bir çok faydalar sağlamak mümkündür. Karakterin teşekkülünde terbiyevî bir rolü olan izciliğge amacına uygun bir çalışma şekli verilirse gençlik ve mem- 
leket bakımından çok faydalı sonuçlar elde edilecektir. Bütün mesele gençleri yetiştirecek olan mürebbilerin gereken bilgi ve meziyetlere mâlik olmaları cihetidir. Zira gençlerle uğraşmak ve hele bir kampı idare etmek özel bir psikoloji bilgisini gereklendirir (5).

\section{2) ÇOCUK ESIRGEME KURUMU:}

Memleketimizde sosyal yardim alanında büyük işler başaran diğer bir teşekkiil de Çocuk Esirgeme Kurumudur. 1921 yılında Ankara'da on arkadaşın aralarinda topladikları yirmi lira ile işe başıyan kurum bugün Türk çocuklarının sağhğını koruyan değerli bir varlık haline gelmiştir.

"Türkiye Himayei Etfal Cemiyeti» adı altında çalışmağa başıyan "Türkiye Çocuk Esirgeme Kurumu" 12 yaşına kadar bütün çocuklarla ilgilenmekle' beraber, gayret ve yardımlarını daha çok süt çocukları üzerinde toplamıştır.

Çocuk Esirgeme Kurumu 25 yıl içerisinde çocuk sağlığı ve nüfus davamız yolunda küçümsenmiyecek başarnlar elde etmiştir. Bilkassa Kurumun Ankaradaki merkez binasinda önemli sosyal hizmetler yapulmaktadir. Gebe kadınlar muayene edilmekte ve kendilerine çocuk bakımı hakkında bilgi verilmektedir. Çalışan ve çocuğunu emzirmek için yeter derecede sütü olmayan fakir annelere parasız süt dağıtılmaktadır. Kurumun çocuk mütahassısı tarafından çocuklar muayene ve tedavi olunmaktadurlar. Bundan başka ziyaretçi hemşireler vasitasile çocuklar evlerinde de takip ve kontrol edilirler. Fakir çocuklar için parasız banyo teşkilâtı meydana getirilmiştir. Kimsesiz çocuklar açık ve kapalı havuzlardan, çocuk bahçesinde neşe ve sağlık kazanırlar. İşe giden annelerin çocıkklarını bıraktıłkları "Günđüz bakım evi" ise iki kısma ayrılmış, süt çocukları ile oyun çocukları ayrı itina ve yardıma tâbi tutulmuştur. Bu suretle gündüz bakımevinde çocuklar anneleri işten dönünceye kadar, hem beslenmekte ve hem neşeli ve faydalı bir şekilde vakit geçirmektedirler.

1925 yılında Keçiörende kurulan ve her yil genişleyen "Çocuk Yuvası) ise bugün gerçek bir varlık olmuş ve buraya almmak saadetine ulaşan yüzlerce kimsesiz Türk çocuğunun hayatını kurtarmış ve geleceklerini güven altına almıştır.

Kuruluşunun 24 inci yılını kutlamakta olan Çocuk Esirgeme

(5) Mr. E. Young - Kamp önderliği psikolojisi, rapor, Sümer Basınevi 1945, Ankara. 
Kurumunun gerek merkezde, gerekse illerdeki çalı̧maları nihayet mutevazi saylan gelir kaynakları ile tahdit edilmis bulunmaktadır. Kurumun büyük amacına ulaştı̆̆ı ileri sürülemez. Çocuk davasının en önemli bir memleket davası olduğu anlaşılan memleketimizde bu davayı ele alan ve kendisine amą̧ edinen bu kuruma karşı yurttaşların daha anlayışlı ve daha cömert davranmaları temenni edilmeğe değer bir keyfiyettir.

\section{3) YARDIM SEVENLER DERNEĞİ}

Kamu yararını sağlayan ve sosyal yardım işleri ile uğraşan kurumlar arasında Yardm Sevenler Derneğini de saymak gerekir. 1928 ylında "Kadın Yardm Cemiyeti" adı ile kurulan bu Kurum 1938 yılında "Yardım Sevenler Cemiyetin admı almıs ve gittikçe faaliyetini artırmıştır.

Merkezi Ankarada olan Yardım Sevenler Kurumu çeşitli yurt işleri üzerinde çalı̧̧r ve yoksullara da yardımda bulunur. Kurum gönüllü hastabakıcı yetiştirmeğe ve Türk kadınım teknik bilgi ve çeşitli cephe gerisi işlerine hazrlamağa gayret etmekle beraber, çalışmalarını daha çok sosyal yardım alanında toplamış bulunmaktadır. Kurumun bu sahada yapmak istediği ve yapmakta bulunduğu işler çok şümullüdür. Ve şu çeşitli kolları ihtiva etmektedir:
a) Yoksulların işe yerleştirilmelerini sağlamak ve iş evleri aç- mak;
b) Dispanserler açmak;
c) Öğrenci yurtlam kurmak;
ç) Yoksul annelere doğumdan önce ve sonra yardım etmek;
d) Çalışamıyacak derecede düş̧ün ve yoksulları korumak;
e) Hal ve gidişleri bakımsız olan çocukları korumak;
f) Genç kızlarm genel durumları ile ilgilenmek;
g) Topluluğa yararlı yayınlar yapmak.

Yardım Sevenler Kurumunun amacını teşkil eden bu çeşitli işlerden bir kısmı bu günden gerçekleşmiş bulunmaktadır. Kurumun merkez ve şubeleri tarafından hastalara ilâç dağıtılmakta, veremlilerin sanatoryomlara gönderilmesine çalışılmakta, yeni doğan çocuklara kundak takımları sağlanmakta, yoksul yurttaşların yol paraları ödenmekte, evlenecek genç kızlara ve çalışacak durumda olmayan yoksullara yardım edilmekte, fakirlere yiyecek ve giyecek ve yakacak dağıtıImakta ve yangın ve depremden zarar görenlerin elden geldiği kadar yardımına koşulmaktadır. 
Yardım Sevenler Kurumunun yoksulları çalıştırmak suretile onları sefillikten kurtarmak teşebbüsü ise çok hayrì bir harekettir. Kurum tarafından kurulan dikiş, çorap, nakış ve el işi atelyelerinde çalışan yüzzlerce kimsesiz kadmn ve genç kızlar hem çalışma zevk ve imkânını elde etmişler ve hem de kimseye el açmadan yoksulluktan kurtulmuşlardir

Maddî bir menfaat peşinde koşmadan memlekette yoksulluğu gidermeğe ve düşkün yurttaşları sevindirmeğe çalışan bu hayır kurumlarının başarmakta oldukları sosyal hizmetler küçük görülemez. Bir kaçınm çalışma şeklinin kı̣saca gözden geçirdiğimiz bu kurumların sayısını çoğaltmak ve bu arada bilhassa "Veremle Mücadele» kurumundan bahsetmek mümkündür. Bütün bu hayir kurumlarinın memlekette mevcut olması ögünülmeğe değer bir keyfiyettir. Zira yoksul yurttaşlarına yardım etmek istiyen zengin bir fert kimlere ve ne suretle yardımda bulunacağını lâyikile kestiremediği halde, sosyal hizmetlerde bulunmayı amaç edinen bu kurumiar vasitasiyle yardımların en muhtaç kimselere ve en uygun bir şekilde yapıld1ğını görecektir. Gerçekten hayır" kurumları geniş teşkilât ve elemanlariyle hamiyetli yurttaşların yardımlarım daha isabetli bir şekilde mahalline sarfetmek imkânına maliktirler. Bütün bu imkânlara rağmen bu hayır kurumları eli ile yapılmakta olan yardımlar, gelir kaynaklarının azlığı yüzünden, çok mahduttur. Bir kısım yurttaşlar düşkün hemeinslerine yapmak istedikleri yardmları herhangi bir hayır kurumu vasitasile değil, doğrudan doğruya kendi elleriyle yapmayı tercih ettiklerinden hayır kurumlarına yapıiłan bağış ve yardımlar bu yüzden mahdut kalmaktadır. Hiç şüphesiz bu tarzda ha-. reket geri bir zihniyetin mahsulüdür. Bir yandan hayır kurumları vasıtasiyle yapllacak yardımların doğrudan doğruya yapılan yardimlar kadar faydalı ve mahalline masruf olduğLinu telkin etmek, öte yandan kurumlar tarafindan yaplan yardımlar hakkında yurttaşlara sık sık bilgi ve hatta hesap vermek gerekir. Bugün bazı kurumlar bu iși yapmakta ve zaman zaman faaliyet sonuçlarını gazetelerde ilân etmektedirler. Hayır kurumlarının yalnız faaliyet sonuçlarmı değil, yıllık hesap durumlarını da yurttaşların gözü önüne sermeleri çok faydalı olacaktır. Zira bazı yurttaşların, ferağatla çalışan bu kurumlarm bazan bir devlet dairesini anđıran geniş teşkilâtı karşısında ürkmeleri ve taraflarmdan yapilan yardımların tamamile yoksullara kadar inemiyeceği zannına kapılmaları mümkündür. Bankalar her yıl malî durumlarını nasıl ilân ediyor ve halkın incelemesine sunuyorsa, tamamiyle halkın itimadına dayanan ve en önem- 
li malî inkânlarını bu kaynaktan alan hayır kurumlarmın da aynı şekilde hareket etmeleri ve her çalışma yll sonunda faaliyet ve durumlarını ilân ederek yurttaşların itimadını tazelemeleri yerinde bir hareket sáyllabilir.

Hayır kurumları ne kadar gelişirse gelişsin devlet rnüdahalesine lüzum göstermiyecek bir şekilde yoksulluğu ortadan kaldıracağ1 ileri sürüleméz. Zira yurttaşlarm hamiyet ve yardımı ile sosyal hizmetler görmekte olan hayır kurumlarının imkânları ne de olsa mahduttur. Sosyal yardım işlerini bir kamu hizmeti telâkki etmeden yoksullukla mücadele etmenin tamamiyle müsbet bir sonuç vermesi beklenemez.

\section{Devlet Eli ile. Sosyal yardim:}

Devletin yoksullara yardımda bulunması yeni bir kamu hizmeti değildir. Gelişme devresi geçen yüzyll içinde olmakla beraber, devleti bazı işlerle ödevlendiren "Sosyal hizmetler" in çok eski bir tarihi vardır. Bu hususta ilk hareket İngilterede görülmüș ve Kraliçe Elizabeth devrinde düsskünlere resmî makamlar tarafından yardım yapılmasını sağlayan kanunlar çlkarılmiş ve gereken sosyal yardım kurumları kurulmuştur. 1601 yllında yayınlanan bir kanunla, bugün birer sosyal sigorta konusu olan, hastallk, işsizlik, dulluk, ve ihtiyarlık hallerinde devletin düşkünlere yardımlarda bülunması bir kamu hizmeti olarak kabul edilmiştir (6). Ingilterede başliyan bu hareket yaylmış ve her memleketin bünyesine göre sosyal hizmetler sistemleri meydana getirilmiştir.

Memleketimizde de sosyal yardım işleri bir devlet hizmeti sayllmıs ve 1912 de (16/Şubat/1328) Dahiliye Nezaretine bağlı olmak üzere "Sıhhiye Müdüriyeti Umumiyesi» kurulmuştur. Bu teşkilât ihtiyaçlar karşısınđa genişletilmiş ve Dahiliye Nezaretinden ayrılarak bir Bakanlık haline getirilmiştir. tlk zamanlar yalnız sağlık koruma işleriyle uğraşan bu yeni teşkilât bir müddet sonra sosyal yardım işleri ile de ilgilenmis ve Sağlık ve Sosyal Yardım Bakanlığı (Sıhhiye ve Muaveneti İçtimaiye Vekâleti) admı almıștır.

9/Haziran/1936 tarihli teşkilât kanunu ile «memleketin sihhî şartlarını islah ve milletin ferdî ve içtimaî sihhatine zarar veren âmillerle mücadele ve gelecek nesillerin sıhhatli olarak yetişmesini temin ve halkı sıhhî ve içtimaî muavenete ulaştırmak ve iskân işlerini görmek için kanunlarla kendine verilen vazifeleri yapmakla»

(6) A. D. K. Owen - İngilterede sosyal hizmetler. Çeviren İzzet Eraydın, İdare dergisi. Ocak - Şubat 1946. Say!: 178. 
ödevlendirilmiş olan Sağlık ve Sosyal Yardım Bakanlığı iki ayrı daire halinde kendisinden beklenen hizmetleri başarmağa çalışmaktadir.

Hıfzıssıhha İşleri Dairesi, «Şehir, köy, göçmen hıfzıssıhhası, spor hıfzıssıhhası ve diğer umumî, içtimaî hıfzıssıhhaya müteallik bütün işler ile isstigal ve bunları takip ve murakaben eder. Bakanlığın, topluluğun sağlığmı koruma yolunda yaptığı işler ve harcadı̆̆ı emekler çok önemlidir. Memleket içinde bulaşıcı ve salgın hastalıkları önlemekle ödevli bulunan bakanlık, bilhassa millî bünyemizi tehdit eden sitma, trahom, zührevî hastaliklar ve veremle cidd cadele etmektedir. Bu arada sitmaya karşı açılan olağanüstü savaştan ayrica bahsetmek yerinde olur. Ancak sitma ile mücadele ederken memleketin ekonomik menfaatlarını da unutmamak gerekir. Olağanüstü sıtma kanununun tatbikinde lüzumsuz hassasiyet gösterilecek olursa bu yüzden bahçe ve kavaklıklarla pirinç istihsalinin büyük zararlara uğrayabileceği hatırlanmalıdır. Her şeyden önce yurttaşın sağlığı bizim için değerli olmakla beraber, memleketin ekonomik endişelerini de göz önünde tutmak zorundayız.

Sağlık Bakanlığımın "Içtimaî muavenet işleri dairesì nin faaliyetine gelince: bu alandaki çalışması içtimaî muavenet işleri dairesinin taşıdığı isimle mütenasip değildir. Bakanlığın sosyal yardım cephesi henüz arzu edildiği kadar bir varlhk gösterememiştir. Zira, bakanlığa bağlı birkaç hastahane ve dispanseri idare etmek ve belediyelerle özel teşebbüslere ait banzer yerleri denetlemekle sosyal. yardım hizmeti lâyıkiyle gerçekleşmiş sayılamaz. "Halkı tıbbî ve içtimaî muavenete mazhar eylemek, amacı ile ödevlendirilmiş olan bu bakanlığın sosyal yardım alanında başarması gereken daha bir çok işleri vardir.

Itiraf etmek lâzımdır kì, yardıma muhtaç olan bütün yurttaşlara devletin el uzatması, hazineyi altından kalkamıyacağı derecede ağır bir yük altında brrakabilir. Hele memleketimiz gibi hazineye yüksek gelir sağlayan zengin yurttaşların sayısı nisbeten az ve yardıma muhtaç olanlarm miktarı oldukça fazla olan memleketler de devletin sosyal yardım işlerini lâyikiyle başarmasına maddeten imkân yoktur. İşte, bu imkânsızlık karşısında, Bakanlık sosyal yarđim alanında daha çok bir yol göstericiliği yapmaktạ ve asil sosyal hizmetlerin başarılmasını mahallì idarelere ve belediyelere birakmaktadır. Nitekim, Hıfzıssihha kanununun 4 üncü maddesinde bu hususta şu sarih hüküm vardur: "Doğrudan doğruya şehir ve kasabalar, köyler hıfzissıhhasına veya tibbî ve içtimaî muavenete müteallik işlerin 
ifası belediyelere, idarei hususiyelere ve mahallî idarelere tevdi edilir. Vekâlet indelicap bu idarelere rehber olmak üzere bazı mahallerde nümune tesisatı vücude getirirn.

Görülüyor ki, Devlet bütçesinden düşkün ve fakirlere gerektiği kadar yardım yapmak imkânsızlığı karşısında, sosyal yardım işlerine daha çok mahallî bir mahiyet verilmiştir. Bu sebeple hıfzissihha kanununun 20 inci maddesi, belediyeleri şehir ve kasabaların genel sağlık durumlarını iyileştirmeğe çalışmaktan başka, hastahane, dispanser, süt çocuğu, muayene ve tedavi evi, aceze ve ihtiyar yurtları ve doğun evi tesis ve idaresi gibi çeşitli ssoyal hizn:etleri sağlamakla da sorumlu tutmustur.

Belediyeler kanununa göre, mahallî mahiyette müsterek ve medenî ihtiyaçların karşılanmasi ve giderilmesi amacı yolunda çalışan belediyelerin, diğer bir çok işlerle beraber, şu sosyal hizmet ve yardımları yapmak mükellefiyeti de vardır:

a) Dilencileri dilenmekten menedecek tedbirle: almak;

b) Brrakılmiş ve bulunmuş çocukları, kazaya ve âfete uğrayanları korumak;

c) Fakir ailelerin ikiz çocuklarına, alelûmum öksụz, fakir kimsesesiz çocuklara para, hekim, ilâç, yeme, içıne, geyinme, barinma, tahsil terbiye cihetlerinden yardım etmek, fakir hastalara parasız bakmak, ilâç vermek, fakir cenazeleri parasız kaldırmak, alil, isten âciz olup da bakacak kimsesị olmıyanlara bakmak: *

c) Yetimhane, acezehane, doğum ve emzirme ve mecburî olarak meccani doğum evleri tesisat ve teşkilâtı ve mahalleri, Sağllk ve Sosyal Yardım Bakanlığınca tâyin ve tasdik eciilmek şartiyle tımarhane, fennî tephirhane ve tathir istasyonları vücude getirmek ve işletmek;

d) Yersiz yurtsuz olanlara iş bulmak bunlardar garip olup çalışamıyanları memleketine göndermek, kimsesiz kadın ve çocukları korumak;

e) Fakirler için yatı evleri yapmak ve idare etmek.

Belediyeler Kanunun 15 inci maddesinde strálanmıs olan bu çeşitli sosyal hizmetlerin belediyeler tarafından tamamen ifa edildiği iddia edilemez. Belediyelerimizin gelir kaynakları çok mahdut ve bütçeleri çok mütevazi olduğundan sosyal yardım işleri arzu edildiği nisbette gelişememiştir. Birkaç büyük şehrimız istisna edilecek olursa bütün belediye faaliyetleri yolların süprülmesine ve kaldı- 
rumların tamirine inhisar etmektedir. Bir çok kasabalarda belediye memurlarının aylıkları belediye bütçesinde gideilerin çok önemli bir kısmını teşkil etmektedir. BayındırIlk işleri içirı belediyelere büyük kredi kolaylıkları gösteren İller Bankasmın sosyal yardım kurum ve yapılarmı meydana getirmek üzere maddî imkânlar hazırlaması da temenni edilmeğe değer bir keyfiyettir. Her halde belediyelerin şehir güzelliği kadar sosyal yardım işlerini de desteklemek ve teşvik etmek çareleri de aranıp bulunmalıdır.

Özel teşebbüsler, Hayır kurumlari ve Devlet ve Belediyeler tarafından yapılmakta olan bütün bu yardım ve gayretlere rağmen memleketimizde yoksulluğun önü alınmı̧ saylamaz. Tarihimizde sık sık tekerrür eden uzun savaşlarmn ve Imparatorluğun sonlarında baş gösteren ihmal yıllarınm etkisi altında memleketimizde yoksulluk ekonomik ve sosyal bir dert olarak endişe ve dikkatimizi üzerine çekmektedir. Yaşama seviyesinin çok düşük olduğu memleketimizde asgarî geçim telâkkisi ile yoksulluk arasinda pek cüz'î bir fark vardır. Bu sebeple, sosyal yardım bir kamu hizmeti haline getiren devletin bütün çabalamalarına rağmen yoksuliuğu ortadan kaldirmak mümkün görülememektedir. Esasen devletin sosyal yardım alanında çok ağır giderleri göze alması, vergi kanalı ile elde edilen Devlet gelirinin önemlì bir kısminin topluluğu teșkil eden yurttaşlardan muayyen bir kısmına (yoksullara) tahsis edilmesine yol açar ki, bu şekilde bir âmme hizmeti tèlâkkisi pek doğru görülemez. Bundan başka Devlet eli ile yapılan yardımları ifrata götürerek bir yandan çalışkan ve müteşebbis yurttaşların kazancı yüksek nisbetli vergilerle geniş ölçüde azaltılmış ve öte yandan uyuşukluk ve tenbelliğe bir nevi prim verflmiş olur ki her iki hal de mahzurludur.

Görülüyor ki, şekil ve mahiyeti ne. olursa olsun gerek fert ve gerekse devlet eli ile yapılan sosyal yardımların bir çok zayıf tarafları vardır. Bugiin bir çok memleketlerde en önemili kamu hizmetlerinden sayılmağa başlanan sosyal hizmetler "sosyal yardım" șeklinden ziyade "sosyal sigortalar" vasitasiyle başarılmaktadır.

Sosyal sigortalar, hastalık, ihtiyarlık, kaza, ölüm ve işsizlik gibi bir tek ferde veya onun hak sahiplerine çok ağır g̨elen bazı rizikoların fertlerin omuzundan alınıp geniş bir zümreye, toplulúğa mal edilmesi esasina dayanır.

Sosyal sigortaların sosyal yardımlara en büyük üstünlüğü, sigortalardan prim almak suretiyle meslekî risk esasina dayanan rizikolar müstesna) bir yandan ferdin sorumluluğunu muhafaza etmiş olmasında. öte yandan bu gibi sosyal tehlikeler karşısında topluluğu 
da mesul tutmus olmasindadir. Genel olarak sosyal sigortalarda fert sigorta primlerine iştirak etmek suretile hareket tarzından ve geleceğini güven altına almasından bizzat sorumlu tutulmakta, topluluk ise sadece bir ferde çok ağır gelen rizikoların yükünü paylaşmak suretile basiretli fertleri yoksulluktan kurtarmaktadır.

Sosyal yardımda ferdin herhangi bir yardima mazhar olması topluluğun lùtuf ve ihsanı olduğu halde, sosyal sigortalarda ferdin topluluktan yardim istemesi bir haktır.

Netice olarak diyebilirizki, cemiyet içinde çeșitli sebepler ve rizikolar sonunda baş gösteren yoksulluğun hazineye ağır bir yük teşkil eden geniș bir sosyal yardım teşkilâtı ile değil daha çok ferdin sorumluluğunu ön plânda tutan ve bütün yurttaşlar arasinda bir menfaat birliği yaratmağa çalışan sosyal sigortalar vasitasiyle önlenmesi veya giderilmesi çareleri aranmalıdır. 